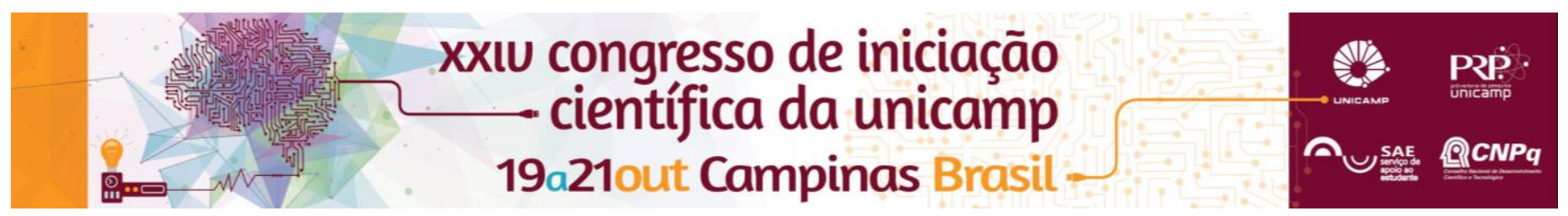

\title{
Atuação de bancos de desenvolvimento no após crise em países selecionados da América Latina: Chile, México e Brasil
}

\author{
Catarina C. C. Silva*, Ana Rosa R. Mendonça
}

\begin{abstract}
Resumo
Este trabalho tem por objetivo analisar a atuação dos bancos públicos de desenvolvimento em países latino americanos selecionados - Chile, México e Brasil -, no enfrentamento dos efeitos da crise financeira internacional iniciada em 2008. O estudo foca nas ações de três bancos específicos: BancoEstado, Banobras e BNDES, respectivamente, chileno, mexicano e brasileiro, perante o sistema financeiro e bancário em que se inserem.
\end{abstract}

\section{Palavras-chave:}

Bancos de desenvolvimento, Brasil, Chile, México.

\section{Introdução}

Bancos públicos de desenvolvimento foram criados na América Latina com o intuito de contribuir para o processo de industrialização na região. Se destacam por gerar mecanismos de financiamento de investimento, que fomentam o desenvolvimento socioeconômico a segmentos restringidos pelos agentes privados. Com a eclosão da crise internacional, o papel dessas instituições se intensificou, tendo sido usadas como veículos de implementação de políticas anticíclicas. Deste modo, estudou-se os sistemas financeiros e bancários dos países selecionados e a atuação de cada banco dentre dele, a fim de evidenciar estas políticas.

\section{Resultados e Discussão}

Com a eclosão da crise financeira internacional, em 2008 , houve uma abrupta restrição de crédito externo, desacelerando e adiando as decisões de investimento. As autoridades políticas, no combate desses sintomas, passaram a utilizar mais intensivamente órgãos públicos como agentes destinados a minimizar os efeitos e acelerar a recuperação. Nesse contexto, bancos públicos de desenvolvimento apresentaram função fundamental, com medidas anticíclicas de expansão de crédito.

O Chile, país como um sistema financeiro e bancário bem desenvolvido e diversificado, com bancos majoritariamente estrangeiros, conseguiu uma rápida recuperação, devido seu sistema robusto e a intervenção das autoridades. $O$ BancoEstado, único banco público do país, estando entre as três principais instituições bancárias, com $15 \%$ da parcela de mercado, tem sua carteira de crédito voltada principalmente ao comércio e habitação. Durante a crise foi responsável por elevar a expansão de crédito frente à retração do resto do sistema.

O México, com um sistema financeiro e bancário pequeno e concentrado, também se constitui basicamente de bancos estrangeiros e privados. Foi fortemente impactado pela crise, mas se manteve resistente, se recuperando no início de 2010. Entre os diversos bancos de desenvolvimento que compõem o sistema, o Banobras se destaca por atuar de forma a promover e solucionar obras de serviços públicos e infraestrutura; pela busca pela ampliação de crédito a municípios e estados, principalmente os com baixos recursos; e por financiar projetos com fonte de pagamento próprio, principalmente no setor de transportes, para cooperar com o desenvolvimento sustentável do México.

O Brasil é marcado por sólidos bancos interno e públicos, sendo $40 \%$ do sistema de propriedade estatal. Durante a crise estes foram responsáveis por conter as restrições de crédito. O BNDES se destaca nesse quesito, atuando com importância fundamental no fomento do desenvolvimento econômico e social ao expandir vorazmente a concessão de crédito, passando a conceder, desde então, valores recordes em desembolso.

\section{Conclusões}

Como se esperava, as instituições analisadas, no período após 2008, exerceram desempenho fundamental na superação da crise, mantendo a oferta de crédito no momento em que outras fontes se retraíram e assegurando a preservação e a expansão dos investimentos.

O BancoEstado, em 2009, apresentou uma evolução do crédito líquido de $22,5 \%$, enquanto no resto do sistema foi de apenas $0,5 \%$. Se destaca também pelo crédito habitacional destinado, principalmente, à população de baixa renda.

Os empréstimos concedidos pelo Banobras foram 2,9 vezes maiores, em 2009, do que a média dos seis anos anteriores. Sua carteira de crédito concentra-se em concessão à entidades federais e municipais, e a projetos do setor privado.

O BNDES, durante a crise, foi responsável por mais de um terço do incremento de crédito na economia brasileira. O total de desembolso continuou a se elevar nos anos seguintes, mostrando os esforços da instituição para a sustentabilidade do crédito na sequência da crise de 2008. Atua principalmente na área de infraestrutura e indústria, focando os micro, pequenos e médios empresários.

\section{Agradecimentos}

Agradeço à professora Ana Rosa de Ribeiro Mendonça pelo apoio e auxílio, desde o início, com o direcionamento na escolha de tema, até a finalização desta pesquisa, e à instituição CNPq/PIBIC pelo financiamento da pesquisa.

BancoEstado. Memoria Anual: Estados Financieros, 2008 a 2014 Banobras. Informe Anual: 2008 a 2014 BNDES. Relatório Anual: 2008 a 2014 